\title{
Grazing strategies, stocking rates, and frequency and intensity of grazing on western wheatgrass and blue grama
}

\author{
R.H. HART, S. CLAPP, AND P.S. TEST
}

\begin{abstract}
Authors are, respectively, range scientist and agricultural research technician, USDA-ARS, High Plains Grasslands Research Station, 8408 Hildreth Road, Cheyenne, Wyo. 82009; and former graduate assistant, Range Management Dept., University of Wyoming, now agricultural extension agent, Oregon State University Extension Service, Box 97, John Day, Ore. 97845.
\end{abstract}

\section{Abstract}

Stocking rates and grazing strategies may alter botanical composition of rangeland vegetation by altering frequency and intensity of defoliation of individual plant species. We used longinterval time-lapse photography to study frequency and intensity of defoliation of western wheatgrass (Pascopyrum smithii [Rydb.] A. Love) and blue grama (Bouteloua gracilis [H.B.K.] Lag. ex Steud.) tillers under continuous season-long and time-controlled short-duration rotation grazing by steers at 2 stocking rates. Frequency, intensity, and variability of defoliation of both grasses were similar under both grazing systems. Western wheatgrass tillers were grazed more frequently under heavy than under moderate stocking, and in 1990 more herbage was removed the second time a tiller was grazed under heavy stocking. Blue grama tillers were grazed more frequently under heavy than under moderate stocking in both years under rotation grazing, but only in 1990 under continuous grazing; more herbage was removed under heavy stocking the second time a tiller was grazed. Under heavy and moderate stocking, respectively, $19 \%$ and $36 \%$ of western wheatgrass tillers and $42 \%$ and $54 \%$ of blue grama tillers were ungrazed throughout the grazing season. Few western wheatgrass tillers were grazed more than twice, and few blue grama tillers were grazed more than once. Stocking rates have much greater potential than grazing systems for altering frequency and intensity of defoliation and subsequent changes in botanical composition of range plant communities. Results of grazing studies support this conclusion.

Key Words: Pascopyrum smithii, Bouteloua gracilis, time-lapse photography, rotation grazing, season-long grazing, grazing systems

Savory (1988) claimed that intensive time-controlled shortduration planned rotation grazing will shift botanical composition of rangeland vegetation toward more palatable, more nutritious, more successionally advanced, and more all-around desirable plant species. This improvement is to be achieved by "hoof action", which improves water and nutrient cycling and favors establishment of desirable plant species, and by control of frequency, severity, and timing of defoliation of key plant species. Inasmuch as considerable doubts have been cast on the benefits of "hoof action" (St. Clair et al. 1984; Balph and Malechek 1985; Graetz and Tongway 1986; Thurow et al. 1986; Weltz and Wood 1986; Warren et al. 1986a, 1986b, 1986c; Abdel-Magid et al. 1987; Pluhar et al. 1987; Weigel et al. 1990; Hart et al. 1993), more attention should be paid

Manuscript accepted 8 Aug. 1992. to the effects of grazing strategies on frequency and intensity of defoliation.

Increasing stocking rate increased frequency and severity of defoliation (Hart and Balla 1982, Briske and Stuth 1982, Curll and Wilkins 1982, Pierson and Scarnecchia 1987, Ruyle et al. 1988). Grazing strategies have much less effect. Gammon and Roberts (1978a, 1978b, 1978c) found no significant differences in defoliation frequency and intensity between continuous and 6-paddock rotational grazing. Gillen et al. (1990) reported little effect of grazing schedule on percent of tillers defoliated or height to which tillers were defoliated.

In all these studies except Hart and Balla (1982), the techniques used required frequent and intensive measurements of individual plants, with considerable disturbance of the stand. Hart (1970) pioneered the use of long-interval time-lapse photography for nondestructive estimates of grazing effects on individual plants. Hart and Balla (1982) used the technique to estimate frequency and intensity of grazing of western and crested wheatgrass (Pascopyrum smithii [Rydb.] A. Love and Agropyron desertorum [Fisch.] Schult.), and Springfield (1974) used it to estimate forage production and utilization of shrubs. Stuth et al. (1987) used time-lapse photography at 5-minute intervals to monitor grazing of 0.1 ha areas of grassland.

Western wheatgrass and blue grama (Bouteloua gracilis [H.B.K.] Lag. ex Steud.) are major constituents of range vegetation and cattle diets on mixed-grass prairie rangelands in the Central High Plains (Samuel and Howard 1982). Black et al. (1937) found that blue grama was much less affected by clipping than was western wheatgrass. Clarke et al. (1947) found that forage production of needleandthread (Stipa comata Trin. \& Rupr.) was affected more by frequency of use than was that of blue grama. Buwai and Trlica (1977a, 1977b) found that multiple defoliations of western wheatgrass produced proportionately greater reductions in subsequent herbage production and total nonstructural carbohydrate concentration than did similar defoliations of blue grama. Therefore, one might expect that increasing frequency and intensity of defoliation would reduce the proportion of western wheatgrass in the stand and increase that of blue grama.

Intensive rotation grazing might decrease the patchiness of grazing often observed under season-long grazing. Under season-long grazing, up to $22 \%$ of western wheatgrass tillers and $16 \%$ of crested wheatgrass tillers were not grazed at all, while up to $51 \%$ and $59 \%$, respectively, were grazed 3 or more times (Hart and Balla 1982). Hormay and Evanko (1958) found $40 \%$ of Idaho fescue (Festuca idahoensis Elmer) plants were overgrazed (stubble $2.5 \mathrm{~cm}$ or shorter) while $15 \%$ were not grazed at all. Rotation grazing also 
removes animals from each paddock before they have a chance to graze new regrowth of previously grazed plants. This may benefit the more palatable plant species.

Changing the frequency and intensity of defoliation of plant species might alter botanical composition and condition of rangelands. We tested the hypotheses that increasing stocking rate would increase frequency and intensity of defoliation of western wheatgrass and blue grama, but that grazing strategy would not. However, intensive rotation grazing might reduce variability in the amount of forage removed per tiller and thus increase uniformity of grazing.

\section{Materials and Methods}

This experiment was conducted as part of the grazing study reported by Hart et al. (1988). Pastures were grazed 16 June-27 October 1983 at 1 steer/3.0 ha (moderate stocking, $M$ ) or 2.25 ha (heavy stocking, H). They were grazed 4 June-10 October 1990 at 1 steer $/ 2.4$ ha $(M)$ or 1.8 ha $(H)$. Forage production (peak standing crop) and utilization [(peak standing crop - end-of-season residue)/ peak standing crop] were estimated as described in Hart et al. (1988).

In 1983, a pair of $25-\mathrm{m}$ transects were laid out in each continuously grazed pasture under heavy and moderate stocking and in one paddock of each short-duration rotationally grazed pasture under heavy and moderate stocking in 1 of the 2 replications. Along 1 transect of each pair, the western wheatgrass tiller nearest each 1-m mark was encircled by a poultry leg band wired to a spike, and the spike was driven into the ground. Along the other transect, the blue grama tiller nearest each 1-m mark was similarly marked. Five colors of leg bands were used in a regular rotation to aid in identifying the number of each tiller along a transect.

In 1990, 2 pairs of 10-m transects were laid out in each continuously grazed pasture under heavy and moderate stocking and in 1 paddock of each short-duration rotationally grazed pasture under heavy and moderate stocking in both replications. Western wheatgrass tillers were marked along 1 transect of each pair and blue grama tillers along the other transect as in 1983.

Thus in 1983, 25 tillers of each grass species were identified in each grazing system $\times$ stocking rate combination, all in replication 1. In 1990, 40 tillers of each species were identified in each combination, 20 in each replication.

At intervals marked tillers were photographed against a gridded background. Date and pasture identification were on cards attached to the background; tiller numbers were on dials built into the background. Tillers in short-duration rotationally grazed pastures were photographed at the beginning and end of each grazing period, 3 per year, in the paddock where they were located. Tillers in continuously grazed pastures were photographed at 14- to 25 day intervals in 1983 and 21- to 34-day intervals in 1990, with 3 dates each year within 1 to 3 days of the beginning of a grazing period on the short-duration rotationally grazed pastures. There were 2 exceptions. The last interval in 1983, from near the beginning of the last grazing period under rotation grazing to the end of grazing, was 36 days. In 1990, tillers under continuous grazing were photographed 31 August near the beginning of the last grazing period under rotation grazing, but the photographs were ruined during developing and tillers were re-photographed 12 September. Dates on which tillers were photographed are listed in Table 1. When a leg band marking a tiller disappeared, a similar replacement tiller was marked. Only 6 tillers were replaced during the 2 years, and no tillers were lost to senescence.

At the end of each year, photographs of each tiller were put in chronological order and examined. If a tiller had been grazed between 2 consecutive photographs, the percent removed was estimated from reductions in tiller height and leaf size and number.
Table 1. Dates on which marked tillers were photographed under seasonlong continuous or short duration rotation grazing strategies, 1983 and 1990.

\begin{tabular}{|c|c|c|c|}
\hline \multicolumn{2}{|c|}{1983} & \multicolumn{2}{|c|}{1990} \\
\hline Continuous & Rotation & Continuous & Rotation \\
\hline \multicolumn{4}{|c|}{$\ldots-\ldots$ Date photographed $\ldots \ldots$} \\
\hline 24 Jun & $23 \mathrm{Jun}$ & 22 May & $18 \mathrm{Jun}$ \\
\hline $8 \mathrm{Jul}$ & 28 Jun & 18 Jun & 21 Jun \\
\hline $28 \mathrm{Jul}$ & $27 \mathrm{Jul}$ & $19 \mathrm{Jul}$ & $18 \mathrm{Jul}$ \\
\hline 11 Aug & 4 Aug & 22 Aug & $24 \mathrm{Jul}$ \\
\hline 1 Sep & $29 \mathrm{Sep}$ & $12 \mathrm{Sep}$ & 30 Aug \\
\hline $26 \mathrm{Sep}$ & 6 Oct & 12 Oct & 7 Sep \\
\hline 1 Nov & & & \\
\hline
\end{tabular}

If a tiller had grown, the percent growth was estimated.

In 1983, because transects were not replicated, chi-square was first computed for each grass from the data on number of times grazed during grazing season, with 4 classes (grazed $0,1,2$, or 3 times) within 4 populations ( $\mathrm{CM}, \mathrm{CH}, \mathrm{SM}$, and $\mathrm{SH}$ ). When significant $(P \leq 0.05)$ differences were detected among populations, chisquare values were computed for the appropriate subsets of data. Data on percent removed at each grazing was analysed as 4 populations with unequal sample numbers.

In 1990, data on times grazed and percent removed was subjected to analysis of variance, first with grazing strategies and stocking rates as treatments and sub-treatments, respectively, blocks as replications, and transects within blocks as sub-samples. As block effects never approached significance ( $P \leq 0.05$ ), data were re-analysed with blocks, blocks $\times$ treatments and subtreatments, and transects within blocks pooled as the error term. When analysis of variance indicated significant differences $(P \leq 0.05)$, Tukey's Highest Significant Difference was used to separate means.

\section{Results and Discussion}

Grazing strategies had no effect on peak standing crop or utilization. Peak standing crop was $1,670 \mathrm{~kg} / \mathrm{ha}$ in 1983 and $1,560 \mathrm{~kg} / \mathrm{ha}$ in 1990 . Utilization was estimated at $44 \%$ and $48 \%$ under moderate and heavy grazing, respectively, in 1983 and $39 \%$ and $48 \%$ in 1990.

Grazing strategy had no effect on the percent of western wheatgrass tillers grazed once, twice, 3 times, or not at all; data from continuous and rotation grazing are pooled in Table 2. Stocking rates had marked effects. In both years, fewer tillers were ungrazed under heavy than under moderate stocking. In 1983, more wheatgrass tillers were grazed once under heavy than under moderate stocking, but not in 1990 , when more tillers were grazed twice under heavy stocking. In 1983 only $4 \%$ of the western wheatgrass tillers observed were grazed 3 times; in 1990 none were.

In 1983, an average of $73 \%$ of aboveground biomass was removed from wheatgrass tillers grazed the first time; from tillers grazed a second time, $74 \%$ of the remaining biomass was removed. Neither strategy nor stocking rate had any effect on percent biomass removed. At the first grazing in 1990, more was removed from western wheatgrass under rotation than under continuous grazing at the moderate, but not at the heavy, stocking rate (Table 3). Within strategies, stocking rate had no effect. At the second grazing, $39 \%$ was removed under moderate vs. $74 \%$ under heavy stocking.

Hart and Balla (1982) reported that increasing stocking rate markedly increased frequency of grazing of western wheatgrass but only occasionally increased the amount removed. They also reported higher frequencies of grazing than were observed in this study, with some tillers grazed 4 times. Forage production in the 2 
Tahle 2. Frequency of grazing of western wheatgrass and blue grama tillers under season-long continuous or short-duration rotation grazing strategies and moderate or heavy stocking rates, 1983 and 1990.

\begin{tabular}{|c|c|c|c|c|c|c|c|}
\hline \multirow[b]{2}{*}{ Grass } & \multirow[b]{2}{*}{ Year } & \multirow[b]{2}{*}{ Strategy } & \multirow[b]{2}{*}{ rate } & \multicolumn{4}{|c|}{ 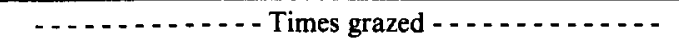 } \\
\hline & & & & 0 & 1 & 2 & 3 \\
\hline $\begin{array}{l}\text { Western } \\
\text { wheatgrass }\end{array}$ & $\begin{array}{l}1983 \\
1990\end{array}$ & $\begin{array}{l}\text { Continuous } \\
\& \text { rotation } \\
\text { Continuous } \\
\& \text { rotation }\end{array}$ & $\begin{array}{l}\text { Moderate } \\
\text { Heavy } \\
\text { Moderate } \\
\text { Heavy }\end{array}$ & $\begin{array}{l}31 \mathrm{a} \\
17 \mathrm{~b} \\
39 \mathrm{a} \\
20 \mathrm{~b}\end{array}$ & $\begin{array}{l}-\% o \\
43 \mathrm{~b} \\
67 \mathrm{a} \\
51 \mathrm{~b} \\
55 \mathrm{ab}\end{array}$ & $\begin{array}{l}\text { zed - - } \\
22 \mathrm{a} \\
12 \mathrm{~b} \\
10 \mathrm{~b} \\
25 \mathrm{a}\end{array}$ & $\begin{array}{l}-- \\
4 a \\
4 a \\
0 a \\
0 a\end{array}$ \\
\hline Blue grama & 1983 & $\begin{array}{l}\text { Continuous } \\
\text { Rotation } \\
\text { Continuous } \\
\text { Rotation }\end{array}$ & $\begin{array}{l}\text { Moderate } \\
\text { Heavy } \\
\text { Moderate } \\
\text { Heavy } \\
\text { Moderate } \\
\text { Heavy } \\
\text { Moderate } \\
\text { Heavy }\end{array}$ & $\begin{array}{l}60 \mathrm{a} \\
56 \mathrm{ab} \\
64 \mathrm{a} \\
48 \mathrm{~b} \\
32 \mathrm{~b} \\
28 \mathrm{~b} \\
58 \mathrm{a} \\
38 \mathrm{~b}\end{array}$ & $\begin{array}{l}32 \mathrm{~b} \\
40 \mathrm{ab} \\
32 \mathrm{~b} \\
48 \mathrm{a} \\
63 \mathrm{a} \\
60 \mathrm{a} \\
40 \mathrm{~b} \\
54 \mathrm{a}\end{array}$ & $\begin{array}{c}8 \mathrm{a} \\
4 \mathrm{a} \\
4 \mathrm{a} \\
4 \mathrm{a} \\
5 \mathrm{bc} \\
12 \mathrm{a} \\
2 \mathrm{c} \\
8 \mathrm{~b}\end{array}$ & $\begin{array}{l}0 \mathrm{a} \\
0 \mathrm{a} \\
0 \mathrm{a} \\
0 \mathrm{a} \\
0 \mathrm{a} \\
0 \mathrm{a} \\
0 \mathrm{a} \\
0 \mathrm{a}\end{array}$ \\
\hline
\end{tabular}

a,bercentages for the same grass, year, and column, followed by the same letter, are not significantly different $(P \leq 0.05)$.

years of their study was much lower, 970 and $1,020 \mathrm{~kg} / \mathrm{ha}$, than the 1,670 and $1,560 \mathrm{~kg} / \mathrm{ha}$ recorded in the 2 years of this study. Grazing pressure of Hart and Balla (1982) was 15.9-32.4 cow-calf days $/ \mathrm{Mg}$ of forage produced, vs. 26.5-45.6 steer-days/ Mg in this study. Hart and Balla's (1982) grazing seasons were $110,143,147$, and 185 days vs. 133 and 128 days in 1983 and 1990, respectively.

Table 3. Herbage removed from western wheatgrass and blue grama tillers at the first grazing under season-long continuous or short-duration rotation grazing strategies and moderate or heavy stocking rates, 1983 and 1990.

\begin{tabular}{|c|c|c|c|c|c|c|}
\hline \multirow[b]{2}{*}{ Grass } & \multirow[b]{2}{*}{ System } & \multirow[b]{2}{*}{$\begin{array}{l}\text { Stocking } \\
\text { rate }\end{array}$} & \multicolumn{2}{|c|}{1983} & \multicolumn{2}{|c|}{1990} \\
\hline & & & Mean & $\begin{array}{c}\text { Std } \\
\text { error }\end{array}$ & Mean & $\begin{array}{c}\text { Std } \\
\text { error }\end{array}$ \\
\hline $\begin{array}{l}\text { Western } \\
\text { wheatgras }\end{array}$ & $\begin{array}{l}\text { Continuous } \\
\text { Rotation }\end{array}$ & $\begin{array}{c}\text { Moderate } \\
\text { Heavy } \\
\text { Moderate } \\
\text { Heavy }\end{array}$ & $\begin{array}{l}71 \mathrm{a} \\
75 \mathrm{a} \\
69 \mathrm{a} \\
76 \mathrm{a}\end{array}$ & $\begin{array}{l}-\% \text { re } \\
5.7 \\
5.4 \\
6.5 \\
6.1\end{array}$ & $\begin{array}{l}\text { oved - } \\
70 \mathrm{~b} \\
60 \mathrm{bc} \\
90 \mathrm{a} \\
79 \mathrm{ab}\end{array}$ & $\begin{array}{l}5.4 \\
5.3 \\
1.5 \\
4.2\end{array}$ \\
\hline Blue grama & $\begin{array}{l}\text { Continuous } \\
\text { Rotation }\end{array}$ & $\begin{array}{c}\text { Moderate } \\
\text { Heavy } \\
\text { Moderate } \\
\text { Heavy }\end{array}$ & $\begin{array}{l}34 a \\
40 a \\
46 a \\
40 a\end{array}$ & $\begin{array}{l}7.0 \\
4.7 \\
7.1 \\
6.9\end{array}$ & $\begin{array}{l}57 a \\
49 a \\
50 a \\
54 a\end{array}$ & $\begin{array}{l}4.8 \\
3.5 \\
7.3 \\
5.2\end{array}$ \\
\hline
\end{tabular}

a,b Means for the same grass and year, followed by the same letter, are not significantly different $(P \leq 0.05)$

Under continuous grazing, the only effect of stocking rate on frequency of grazing on blue grama occurred in 1990. Although few tillers were grazed twice under any treatment, in 1990 more were grazed twice under heavy stocking under both grazing strategies. But under rotation grazing, fewer tillers were ungrazed and more were grazed once under heavy than under moderate stocking in both years. The probability that a blue grama tiller will be grazed increases with increasing stocking rate, and the increase is greater under rotation grazing. No blue grama tillers were grazed 3 times.

Percent of biomass removed from blue grama tillers at the first grazing was unaffected by strategy or stocking rate in either year; $40 \%$ was removed in 1983 and $52 \%$ in 1990 (Table 3), again reflecting higher stocking rate in 1990. At the second grazing, more was removed under heavy stocking than under moderate, $100 \%$ vs. $45 \%$ in 1983 and $72 \%$ vs. $45 \%$ in 1990 , although the difference was significant ( $P \leq 0.05$ ) only in 1983 and few tillers were grazed twice under any treatment. Strategy had no effect on intensity of defoliation.

Western wheatgrass tillers that were regrazed after the first grazing were those from which less herbage $(P \leq 0.05)$ was removed at the first grazing. In 1983, tillers grazed twice had 55\% of their biomass removed at the first grazing, vs. $79 \%$ removed from tillers not grazed again. In $199060 \%$ and $75 \%$, respectively, were removed at the first grazing from tillers regrazed later and those not grazed again. No significant differences were observed in blue grama; tillers regrazed later lost $39 \%$ at the first grazing vs. $46 \%$ from tillers not regrazed.

Variation in the amount of herbage removed at the first grazing was not much influenced by stocking rate or grazing system. The standard error of the amount removed at the first grazing was not significantly higher under rotational than under continuous grazing, except on western wheatgrass tillers in the moderately stocked pastures in 1990 (Table 3). Variation in defoliation among tillers on the same plant may be advantageous. Forage production may be greater after defoliation to different heights or defoliation of only some of the available plants or tillers than after uniform defoliation (Matches 1966, Smith 1968, Smith et al. 1975, Stroud et al. 1985).

One of the objectives of rotation or planned grazing is to prevent early grazing or regrowth (Savory 1988). But in the case of western wheatgrass this objective may be irrelevant because western wheatgrass produces little re-growth after mid-July, regardless of treatment. Under continuous grazing in 1983, biomass of ungrazed wheatgrass tillers increased $16 \%$ from 24 June to 8 July but only $3 \%$ for the rest of the season. Biomass of ungrazed western wheatgrass tillers increased $15 \%$ from 28 June to 27 July under rotation grazing, but only $2 \%$ from then until the end of the grazing season. Most of this growth probably occurred early in the period. In 1990 , biomass increased $35 \%$ from 21 June to 18 July under rotation grazing and $39 \%$ from 18 June to 19 July under continuous grazing, but only $5 \%$ and $1 \%$ thereafter under rotation and continuous grazing, respectively. Both 1983 and 1990 were very favorable years, with forage production of 1,670 and $1,560 \mathrm{~kg} /$ ha respectively, well above the average of approximately $1,100 \mathrm{~kg} / \mathrm{ha}$ (Hart 1991). Blue grama tillers continue to grow through August, but again regrowth is not a management consideration because so few tillers are grazed more than once.

Frequency and occasionally intensity of grazing of western wheatgrass and blue grama tillers increased with stocking rate. Similar responses have been previously reported in crested and western wheatgrasses (Hart and Balla 1982), brownseed paspalum (Paspalum plicatulum Michx.; Briske and Stuth 1982), perennial ryegrass (Lolium perenne L.; Curll and Wilkins 1982), intermediate wheatgrass (Elytrigia intermedia [Host] Nevski; Pierson and Scarnecchia 1987), and Lehmann lovegrass (Eragrostis lehmanniana Nees; Ruyle et al. 1988). Because severe defoliation is usually 
less damaging to blue grama than to western wheatgrass, blue grama often increases as stocking rate increases, while western wheatgrass decreases (Sarvis 1941, Klipple and Costello 1960, Houston and Woodward 1966, Launchbaugh 1967, Sims et al. 1976).

In conclusion, grazing strategies had little effect on frequency, severity or variation of grazing of western wheatgrass or blue grama. Therefore it is not surprising that grazing strategies have had little effect on botanical composition of rangelands (Sarvis 1941; Denny and Barnes 1977; Denny and Steyn 1977; Denny et al. 1977; Gammon and Roberts 1978a; Heitschmidt et al. 1985, 1987; Pitts and Bryant 1987; Hart et al. 1988; Bryant et al. 1989; Taylor 1989).

\section{Literature Cited}

Abdel-Magid, A., G.E. Schuman, and R.H. Hart. 1987. Soil bulk density and water infiltration as affected by grazing systems. J. Range Manage. 40:307-309.

Balph, D.F., and J.C. Malecheck. 1985. Cattle trampling of crested wheatgrass under short-duration grazing. J. Range Manage. 38:226-227.

Black, W.H., A.L. Baker, V.I. Clark, and O.R. Mathews. 1937. Effects of different methods of grazing on native vegetation and gains of steers in northern Great Plains. USDA Tech. Bull, 547.

Briske, D.D., and J.W. Stuth. 1982. Tiller defoliation in a moderate and heavy grazing regime. J. Range Manage. 35:511-514.

Bryant, F.C., B.E. Dahl, R.D. Pettit, and C.M. Britton. 1989. Does shortduration grazing work in arid and semiarid regions? J. Soil \& Water Conserv. 44:290-296.

Buwai, M., and M.J. Trlica. 1977a. Defoliation effects on root weights and total nonstructural carbohydrates of blue grama and western wheatgrass. Crop Sci. 17:15-17.

Buwai, M., and M.J. Trlica. 1977b. Multiple defoliation effects on herbage yield, vigor, and total nonstructural carbohydrates of five range species. J. Range Manage. 30:164-171.

Clarke, S.E., E.W. Tisdale, and N.A. Skoglund. 1947. The effects of climate and grazing practices on short-grass prairie vegetation in southern Alberta and southwestern Saskatchewan. Exp. Farms Serv. Publ. 747, Tech. Bull. 46.

Curll, M.L., and R.J. Wilkins. 1982. Frequency and severity of defoliation of grass and clover by sheep at different stocking rates. Grass \& For. Sci. 37:291-297.

Denny, R.P., and D.L. Barnes. 1977. Trials of multi-paddock grazing systems on veld. 3. A comparison of six grazing procedures at two stocking rates. Rhod. J. Agr. Res. 15:129-142.

Denny, R.P., D.L. Barnes, and T.C.D. Kennan. 1977. Trials of multipaddock grazing systems on veld. 1. An exploratory trial of systems involving twelve paddocks and one herd. Rhod. J. Agr. Res. 15:11-23.

Denny, R.P., and J.S.H. Steyn. 1977. Trials of multi-paddock grazing systems on veld. 2. A comparison of a 16-paddocks-to-one-herd system with a four-paddocks-to-one-herd system using breeding cows. Rhod. J. Agr. Res. 15:119-127.

Gammon, D.M. 1978. Patterns of defoliation during continuous and rotational grazing of rangeland by cattle. Proc. Ist Int. Rangeland Congress. Soc. Range Manage., Denver, Colo. 603-605.

Gammon, D.M., and B.R. Roberts. 1978a. Patterns of defoliation during continuous and rotational grazing of the Matopos Sandveld of Rhodesia. 1. Selectivity of grazing. Rhod. J. Agr. Res. 16:117-131.

Gammon, D.M., and B.R. Roberts. 1978b. Patterns of defoliation during continuous and rotational grazing of the Matopos Sandveld of Rhodesia. 2. Severity of defoliation. Rhod. J. Agr. Res. 16:113-145.

Gammon, D.M., and B.R. Roberts. 1978c. Patterns of defoliation during continuous and rotational grazing of the Matopos Sandveld of Rhodesia. 3. Frequency of defoliation. Rhod. J. Agr. Res. 16:147-164.

Gillen, R.L., F.T. McCollum, and J.E. Brummer. 1990. Tiller defoliation patterns under short duration grazing in tallgrass prairie. J. Range Manage. 43:95-99.

Graetz, R.D., and D.J. Tongway. 1986. Influence of grazing management on vegetation, soil structure and nutrient distribution and the infiltration of applied rainfall in a semi-arid chenopod shrubland. Aust. J. Ecol. $11: 347-360$.

Hart, R.H. 1970. Frequency and severity of defoliation of crownvetch stems by grazing sheep. Agron. J. 62:626-627.

Hart, R.H. 1991. Managing cattle for risk-the STEERISK spread-sheet. J. Range Manage. 44:227-231.
Hart, R.H., and E.F. Balla. 1982. Forage production and removal from western and crested wheatgrass under grazing. J. Range Manage. 35:362-366.

Hart, R.H., J. Bissio, M.J. Samuel, and J.W. Waggoner, Jr. 1993. Grazing systems, pasture size, and cattle grazing behavior, distribution, and gains. J. Range Manage. 46:81-87.

Hart, R.H., M.J. Samuel, P.S. Test, and M.A.Smith. 1988. Cattle, vegetation, and economic responses to grazing systems and grazing pressure. $J$. Range Manage. 41:282-286.

Heitschmidt, R.K., S.L. Dowhower, R.A. Gordon, and D.L. Price. 1985. Response of vegetation to livestock grazing at the Texas Experimental Ranch. Texas Agr. Exp. Sta. B-1515.

Heitschmidt, R.K., S.L. Dowhower, and J.W. Walker. 1987. 14- vs. 42 paddock rotational grazing: aboveground biomass dynamics, forage production, and harvest efficiency. J. Range Manage. 40:216-223.

Hormay, A.L., and A.B. Evanko. 1958. Rest-rotation grazing-a management system for bunchgrass ranges. U.S. Forest Serv. Misc. Paper 27.

Houston, W.R., and R.R. Woodward, 1966. Effects of stocking rates on range vegetation and beef cattle production in the Northern Great Plains. USDA Tech. Bull. 1357.

Klipple, G.E., and D.F. Costello. 1960. Vegetation and cattle responses to different intensities of grazing on shortgrass ranges on the Central Great Plains. USDA Tech. Bull. 1216

Launchbaugh, J.L. 1967. Vegetation relationships associated with intensity of summer grazing on a clay upland range site in the Kansas 20- to 24-inch precipitation zone. Kansas Agr. Exp. Sta. Tech. Bull. 154.

Matches, A.G. 1966. Influence of intact tillers and height of stubble on growth responses of tall fescue (Festuca arundinacea Schreb.) Crop Sci. 6:484-487.

Norton, B.E., and P.S. Johnson. 1983. Patterns of defoliation by cattle grazing crested wheatgrass pastures. Proc. Int. Grassl. Congr. XIV:462-464.

Pierson, F.B., and D.L. Scarnecchia. 1987. Defoliation of intermediate wheatgrass under seasonal and short-duration grazing. J. Range Manage. 40:228-232.

Pitts, J.S., and F.C. Bryant. 1987. Steer and vegetation response to shortduration and continuous grazing. J. Range Manage. 40:386-389.

Pluhar, J.J., R.W. Knight, and R.K. Heitschmidt. 1987. Infiltration rates and sediment production as influenced by grazing systems in the Texas Rolling Plains. J. Range Manage. 40:240-243.

Ruyle, G.B., P.R. Ogden, and R.W. Rice. 1988. Defoliation patterns of cattle grazing Lehmann lovegrass. Appl. Agr. Res. 3:177-181.

St. Clair, L.L., B.L. Webb, J.R. Johansen, and G.T. Nebeker. 1984. Cryptogamic soil crusts: Enhancement of seedling establishment in disturbed and undisturbed areas. Reclaim. Reveg. Res. 3:129-136.

Samuel, M.J., and G.S. Howard. 1982. Botanical composition of summer cattle diets on the Wyoming High Plains. J. Range Manage. 35:305-308.

Sarvis, J.T. 1941. Grazing investigations on the Northern Great Plains. North Dakota Agr. Exp. Sta. Bull. 308.

Savory, A. 1988. Holistic resource management. Island Press, Covelo, Calif.

Sims, P.L., B.E. Dahl, and A.H. Denham. 1976. Vegetation and livestock response at three grazing intensities on sandhill rangeland in eastern Colorado. Colorado State Univ. Exp. Sta. Tech. Bull. 130.

Smith, A. 1968. Sward growth in relation to pattern of defoliation. J. Brit. Grassl. Soc. 23:294-298.

Smith, A., R.A. Arnott, and J.R. Macauley. 1975. Sward productivity under alternate or repeated cutting of adjacent small areas. J. Brit. Grassl. Soc. 30:201-208.

Springfield, H.W. 1974. Using a grid to estimate production and utilization of shrubs. J. Range Manage. 27:76-78.

Stroud, D.O., R.H. Hart, M.J. Samuel, and J.D. Rodgers. 1985. Western wheatgrass responses to simulated grazing. J. Range Manage. 38:103-108.

Stuth, J.W., P.S. Grose, and L.R. Roath. 1987. Grazing dynamics of cattle stocked at heavy rates in a continuous and rotational grazed system. $J$ Appl. Anim. Beh. Sci. 12:1-9.

Taylor, C.A. Jr. 1989. Short-duration grazing: Experiences from the Edwards Plateau region in Texas. J. Soil \& Water Conserv. 44:297-302.

Thurow, T.L., W.H. Blackburn, and C.A. Taylor. 1986. Hydrologic characteristics of vegetation types as affected by livestock grazing systems, Edwards Plateau, Texas. J. Range Manage. 39:505-509.

Warren, S.D., T.L. Thurow, W.H. Blackburn, and N.E. Garza. 1986a. The influence of livest ock trampling under intensive rotation grazing on soil hydrologic characteristics. J. Range Manage. 39:491-495. 
Warren, S.D., W.H. Blackburn, and C.A. Taylor Jr. 1986b. Effects of season and stage of rotation cycle on hydrologic condition of rangeland under intensive rotation grazing. J. Range Manage. 39:486-491.

Warren, S.D., W.H. Blackburn, and C.A. Taylor Jr. 1986c. Soil hydrologic response to number of pastures and stocking density under intensive rotation grazing. J. Range Manage. 39:500-504.
Weltz, M., and M.K. Wood. 1986. Short-duration grazing in central New Mexico: Effects on infiltration rates. J. Range Manage. 39:365-368.

Weigel, J.R., C.M. Britton, and G.R. McPherson. 1990. Trampling effects from short-duration grazing on tobosagrass range. J. Range Manage. 43:92-95. 